\title{
La capital virreinal en La Perricholi. Reina de Lima de Alonso Cueto: historia y literatura, literatura y ciudad
} The Viceregal Capital in La Perricholi. Reina de Lima by Alonso Cueto: History and Literature, Literature and City

\author{
Eva Valero Juan \\ ORCID iD: http://orcid.org/0000-0002-4671-5533 \\ Universidad de Alicante, España
}

En la construcción literaria de Lima a través de los siglos se delinean dos perspectivas: mitificadora y crítica. La primera, originada en los textos coloniales, tuvo un período de especial relevancia a partir de finales del siglo XIX en las obras que recrearon la Lima virreinal a partir de las Tradiciones peruanas de Ricardo Palma. En 2019, un narrador sobresaliente de la ciudad como es Alonso Cueto ha producido la gran novela sobre la capital del final de la Colonia, La Perricholi. Reina de Lima. Al estudio de la novela en su engarce con la tradición, desde los ejes relativos a literatura y ciudad, y literatura e historia, se dedica este trabajo.

Palabras Clave: Alonso Cueto; La Perricholi; Historia y literatura; Literatura y ciudad.

In the literary construction of Lima through the centuries, two perspectives are delineated, the mythicising one and the critical one. The first, generated from the colonial texts, had a period of special relevance from the end of the $19^{\text {th }}$ century in the works that the recreated viceregal Lima from the Tradiciones Peruanas by Ricardo Palma. In 2019, Alonso Cueto, a prominent narrator of the city, produced the great novel about the capital at the end of the colonial period, La Perricholi. Reina de Lima. This article deals with the study of the novel in its link with tradition, from the axes of literature and city, literature and history.

Keywords: Alonso Cueto; La Perricholi; History and Literature; Literature and City.

Copyright: (C) 2020 CSIC. Este es un artículo de acceso abierto distribuido bajo los términos de la licencia de uso y distribución Creative Commons Reconocimiento 4.0 Internacional (CC BY 4.0). 
Abordar la novela publicada por el narrador peruano Alonso Cueto en 2019, La Perricholi. Reina de Lima, ${ }^{1}$ significa introducirse en un nuevo hito, imprescindible, sobre el mítico personaje de Micaela Villegas, cuyo apodo da título a la obra. En la novela, el mito se revela a través de dos grandes ejes sobre los que gira el presente estudio: por un lado, la clásica fusión de historia y literatura, en tanto que la obra recoge todos los acontecimientos y personajes históricos principales que confluyeron en el Perú de la segunda mitad del siglo XVIII y primeras décadas del XIX; por otro, la secular relación entre literatura y ciudad, puesto que nos encontramos ante la gran novela contemporánea sobre la Lima colonial, cuyo emblema principal, en los estertores de la Colonia, fue la legendaria Perricholi.

La vida de esta actriz y cantante de origen humilde que protagonizó la escena teatral de la Lima dieciochesca en el transcurso de su vida, entre 1748 y 1819 , cubre ese arco temporal que concluye en los años previos a la consolidación de la Independencia; por tanto, el período final del virreinato y todo el contexto y el proceso preindependentista que culminaría en 1824 en la batalla de Ayacucho. Sobre ese período convulso de la historia americana, Alonso Cueto ficcionaliza toda una vida - la de la Perricholi- marcada por el romance con el sexagenario virrey Manuel de Amat y Junyent (17611776), con quien tuvo un hijo. Y lo hace al compás de la reconstrucción literaria de la historia del Perú —y de Hispanoamérica — anterior a la Emancipación, creando una amalgama perfecta entre biografía de la Perricholi e historia de la ciudad y del virreinato. Así pues, la obra se inscribe en los límites de la novela histórica tradicional — dilucidados por Georges Lukács-, subgénero que desde su origen se basó, precisamente, en la correspondencia entre una crisis o transformación histórica y una crisis personal de los protagonistas, que en la obra de Cueto viven, como explica Lukács,

las grandes transformaciones de la historia como transformaciones de la vida del pueblo. Su punto de partida está siempre en la presentación de las influencias en la vida cotidiana del pueblo por parte de los importantes cambios históricos, y en la presentación de los cambios materiales y psíquicos provocados por aquellos en los seres humanos que, sin darse cuenta de sus causas, reaccionan sin embargo a ellos en forma inmediata y vehemente. ${ }^{2}$

Tal es el caso de Micaela Villegas, del virrey Amat y de los seres humanos que protagonizaron esas décadas y que aparecen en la novela como actantes de dicha transformación; figuras históricas convertidas en algunos

1 Cueto, 2019.

2 Lukács, 1966, 52-53. 
casos en personajes literarios que en las páginas de Cueto viven permanentemente entre los éxitos y las más íntimas inseguridades, contradicciones y quiebras espirituales.

Nos encontramos, por tanto, ante una novela histórica que es plenamente humana porque los acontecimientos tienen consecuencias constantes en la vida privada de los protagonistas. La mirada hacia el pasado que realiza Cueto resucita, «poéticamente — como explica Lukács — a los seres humanos que figuraron en esos acontecimientos». «Lo importante —añade el teórico- es procurar la vivencia de los móviles sociales e individuales por los que los hombres pensaron, sintieron y actuaron precisamente del modo en que ocurrió la realidad histórica». ${ }^{3}$ Es en esta dirección que la novela crea el universo de toda una época, y por sus páginas desfila una pléyade de personajes históricos a los que me referiré más adelante. En lo que respecta a los personajes protagónicos, lejos de tratarse de seres inmovilizados por la historia, Cueto se propone un objetivo netamente literario que sintetiza en la «Nota del autor», en la que tras decirnos que los libros no se escriben para explicar o interpretar a los personajes, «sino para verlos y sentirlos y seguirnos haciendo preguntas sobre ellos», añade: «Respecto a Micaela, nunca he querido entenderla ni interpretarla ni retratarla sino seguirla y tratar de respirar con ella». ${ }^{4}$ Efectivamente, entre todos los personajes, Micaela Villegas se sitúa en el centro de ese escenario, cuyas imágenes podemos mirar y sentir al compás de su respiración, que acompaña al lector porque su autor la ha atrapado y transmitido con la maestría propia de la gran literatura.

\section{Antecedentes: del Perú a extramuros}

Antes de introducirnos en el análisis de los referidos ejes definitorios de la novela - por otra parte, medulares en la historia de la literatura universal-, conviene fijar el hito de la obra objeto de análisis en su tradición. Me refiero a los antecedentes artísticos que generó este personaje principal de la historia del Perú, convertido en símbolo de esa Lima virreinal que surge en toda su complejidad a lo largo de la novela. Cabe recordar, pues, que la que fuera la comedianta más afamada de la Lima dieciochesca, amante del famoso virrey catalán Manuel de Amat y Junyent, se transformó en una de las figuras principales de la leyenda de la ciudad, pasando a engrosar no solo las

3 Ibidem, 44.

4 Cueto, 2019, 442. 
páginas de la literatura limeña posterior, sino también las de la literatura, la ópera y el cine universales. De hecho, la fascinación suscitada por este personaje fructificó - como resume Cueto en la mencionada «Nota del autor» con la que concluye su novela- en «las películas, las series, las biografías y las novelas» en las que ella es la protagonista. ${ }^{5}$ Encandiló a escritores como Prosper Mérimée, quien en 1829 relató algunas de sus aventuras en la obra teatral aparecida diez años después de la muerte de Micaela Villegas, Le Carrosse du Saint-Sacrement, obra que a su vez inspiró una ópera de 1948 a Henry Busser, de título homónimo, y en 1953 el film de Jean Renoir Le Carrosse d'or. También fascinó a compositores como Jacques Offenbach, que le dedicó la opereta titulada La Périchole, de 1868. Por último, sobresale la novela de Thornton Wilder, El puente de San Luis Rey (Premio Pulitzer en 1928) que, como anota Cueto, «inventa un personaje llamado Camila Perichole viviendo a comienzos del siglo XVIII, antes del nacimiento de Micaela». ${ }^{6}$

En cuanto a la literatura peruana que se ha dedicado a esta protagonista de la Lima virrienal, hay que recordar en primer lugar a Ricardo Palma, que escribió la tradición titulada «Genialidades de la "Perricholi"».? Recreada en las páginas del gran tradicionista como emblema de la Lima del setecientos, resulta de especial interés señalar también, en este mismo sentido, el apunte de otro escritor peruano principal de comienzos del siglo XX, Ventura García Calderón, quien, desde la ciudad en la que se afincó, París, escribió una novela en francés titulada La Périchole (1959). De Ventura García Calderón cabe destacar otra de sus obras, Vale un Perú (1939), donde apuntó que la Perricholi resumía la esencia frívola, pícara y poderosa de las tapadas (las limeñas que vestían la saya y el manto con el que se tapaban dejando ver un solo ojo) para convertirse no solo en icono principal de la Lima dieciochesca, sino en algo mucho más trascendental, en símbolo de la peruanidad integral:

Toda la fama ambulante de las tapadas, durante un siglo de boato y galantería, iba a polarizarse en torno de una mujer venida de provincia. La más famosa limeña, la más típica es una serrana —y debemos bendecir estos aciertos de la casualidad- [...] Sin mucha sutileza podemos ver en ella una armoniosa y viable síntesis de Perú cuando reúne la energía de nuestras altiplanicies a esa sonrisa frívola de Lima, peligrosa porque no toma nada en serio. ${ }^{8}$

5 Ibidem, 442.

6 Idem.

7 Palma, 1894, 299-307.

8 García Calderón, 1939, 121. La cursiva es mía. 
Otro libro emblemático sobre la vida de la actriz es el de Luis Alberto Sánchez titulado La Perricholi, donde el conocido crítico e historiador peruano ofreció, junto a la biografía de la que él llamó «la Cenicienta limeña», ${ }^{9}$ el cuadro suntuoso de esta Lima afrancesada, el empaque y el lujo de sus mujeres, creando además esa simbiosis entre el personaje y la ciudad que, como veremos, llega hasta el siglo XXI con la novela de Cueto:

Ellas, españolas o mestizas, usaban riquísimas telas y abundantes encajes: cuajaban sus dedos de sortijas; hacían tintinear las pesadas pulseras a cada movimiento de sus brazos; deslumbraban con el brillo de sus diademas y collares de perlas, brillantes y piedras preciosas [...]

En 1745, Lima lucía cierto empaque de ciudad grande. La vía pública, poblada de cafés y con notoria vida galante, había roto el dique conventual del siglo anterior. Se hablaba de los tiempos idos con cierto desdén y arrogancia. ${ }^{10}$

A esta cita cabe añadir, en lo que respecta a dicha simbiosis, que, según Sánchez, si en términos generales la limeña imprime el sello propio a la ciudad del XVIII, «la Villegas irremediablemente constituía algo característico de Lima y de una época». ${ }^{11}$ En la misma línea, otro historiador fundamental de las letras peruanas, Mario Castro Arenas, observó que la Lima de dicho siglo, afrancesada, sensual y licenciosa, tuvo como protagonista de excepción el espectáculo escénico, y Micaela Villegas, en el candelero de este escenario, «es la espuma de un proceso social que tipifica o, si se quiere, pervierte, a las mujeres criollas y mestizas de las clases populares». ${ }^{12} \mathrm{En}$ esta tradición sobre el personaje desarrollada desde el siglo XIX, la novela de Cueto se erige en la gran obra actual que recoge, reformula y vivifica los ríos de tinta vertidos — no solo en la escritura sino también, como hemos visto, en el pentagrama y en el guion cinematográfico - sobre este personaje y también sobre la figura fundamental del virrey Amat, en un contexto especialmente fecundo en lo relativo a los acontecimientos históricos y sus protagonistas.

Ahora bien, la novela va mucho más allá de la inscripción en la tradición literaria y artística generada por el personaje. Sus mencionados ejes principales son, asimismo, dos de los ejes vertebradores de la historia de la literatura peruana: la recuperación del pasado colonial y la historia de Lima en la literatura del Perú desde su fundación. En esta historia literaria de la

9 Sánchez, 1971, 116.

10 Ibidem, 16.

11 Ibidem, 148.

12 Castro Arenas, 1964, 27. 
ciudad se detectan dos orientaciones claras que conviven a lo largo de los siglos: por un lado, la construcción textual mitificadora de la urbe, generadora de la leyenda de una Lima virreinal apacible y esplendorosa, centro principal del gran virreinato de América del Sur durante los siglos XVI, XVII y parte del XVIII; por otro, la disolución del mito en textos críticos que se producen también desde los siglos coloniales hasta la tematización de la transformación urbana iniciada hacia mediados del siglo XX. ${ }^{13}$ En esta tradición literaria sobre Lima, la novela de Cueto se erige, como veremos, en obra cumbre que desde el siglo XXI hace confluir la doble vertiente o perspectiva con la que la ciudad fue creciendo en los textos literarios al compás de su expansión y transformación. En suma, dicha visión dual sobre la ciudad reverbera en la novela de Cueto desde una perspectiva actual, permitiendo una mirada abarcadora y especialmente significativa para el devenir de la literatura peruana a través de los siglos.

En relación con esa tradición, la novela de Cueto reescribe la arraigada identificación de la Perricholi con Lima construida a lo largo de la historia, tal y como explicita el narrador hacia la mitad de la obra: «Una mujer capaz de subvertir la realidad y dejar su huella en la música del mundo. El mundo era Lima. Su música era Lima, su cuerpo y sus palabras eran Lima. Sin saberlo, su padre la había convertido en eso. Que ella era capaz de existir para siempre en Lima, y sin él». ${ }^{14}$ Tal identificación, manifiesta en el meridiano de la novela, es el factor explicativo que aporta coherencia al protagonismo doble que se encuentra en sus páginas: el de la Perricholi y el de la propia ciudad. Así, la operación de recuperación es doble y se asemeja: la de una mujer extraordinaria y la de una ciudad asombrosa, ambas fascinantes, ambas contradictorias y ambas en eterna ebullición. Conviene comenzar por esta última, para derivar en la otra y visualizar el conjunto al final.

\section{La novela histórica del siglo XXI sobre la Lima colonial}

«Las ciudades existen, no sólo en la geografía, sino en el espíritu», recordó Raúl Porras Barrenechea. ${ }^{15}$ Desde este punto de vista, la literatura las dota — parafraseando a Julio Ramón Ribeyro — de una segunda realidad complementaria, mítica, trascendente, sobrenatural:

13 He analizado esta temática en Valero, 2003.

14 Cueto, 2019, 295.

15 Porras Barrenechea, 1965, 9. 
La literatura sobre las ciudades las dota de una segunda realidad y las convierte en ciudades míticas. Inversamente, la ausencia de esta literatura las empequeñece. Hay ciudades importantes pero que no han inspirado grandes obras literarias y que por ello mismo siguen siendo sólo eso, ciudades importantes [...] Estas ciudades pueden ser centros de interés político, económico, histórico, urbanístico u otros pero, que yo sepa, carecen de plusvalía literaria, no han dado origen al o los escritores que les agreguen la dimensión sobrenatural de la literatura [...]

Que estas representaciones sean fidedignas no tiene mucha importancia. Si lo son, poseen a parte de su valor estético uno documental, que satisface el gusto de ciertos lectores por lo concreto y permite a historiadores, sociólogos y economistas estudios tan pronto apasionantes como necios. Pero pueden ser también representaciones equivocadas, tendenciosas o fantasistas. La Habana de Lezama Lima puede ser delirante, la Praga de Kafka onírica y el Bagdad de Las Mil y una Noches fabuloso. Pero es gracias a estos autores o libros que dichos espacios dejan de ser espacios geográficos para convertirse en espacios espirituales, santuarios que sirven de peregrinación y de referencia a la fantasía universal. ${ }^{16}$

En la historia de la literatura peruana, fue Ricardo Palma el primer autor que fundó literariamente la ciudad ${ }^{17}$ a través de la recuperación de su intrahistoria en el género de cuño propio que él mismo creó: las Tradiciones peruanas, publicadas entre el último tercio del siglo XIX y comienzos del XX. Si bien a lo largo del periodo colonial se encuentran diversas obras, en prosa y en verso, en las que la ciudad va emergiendo en la doble dimensión ya señalada — mitificadora y crítica-, después de la Independencia el pasado colonial fue clausurado en aras de la necesaria atención al presente y futuro de la nueva nación. ${ }^{18}$ No sería hasta la segunda mitad del siglo XIX cuando la impostergable recuperación de ese pasado se produjera. Palma protagonizó ese proceso, y generó también una tradición posterior de autores que, desde la Generación del Novecientos o arielista, alimentaron la evocación del pasado limeño como hortus clausum virreinal; autores que acentuaron el tono nostálgico del pasado irrecuperable tras la Guerra del Pacífico con Chile en $1879^{19}$ y generaron la tradición de «una Lima que se va», que tiene

16 Ribeyro, 1994, 128-129. La cursiva es mía.

17 Véase Sánchez, 1927.

18 «Al devenir la Independencia se consideró que todo lo pasado inmediato era repudiable y que así como las ideas revolucionarias y progresistas nos vinieron como resultado de los contactos con las ideologías y los acontecimientos universales, lo que era, desde luego, cierto, se pensó que, entregándonos a tal universalismo [...] el progreso modificaría, adecuándolo a las nuevas necesidades, el sistema imperante. De ahí que aquellos ingenuos nuevos ricos del universalismo se lanzaron a borrar todo vestigio pasatista para sustituirlo por apariencias modernistas, de acuerdo a las nuevas normas, sin caer en que, lo que implantaban, no era sino apariencias». Ugarte Elespuru, 1967, 241.

19 «El intento de ingreso en la modernidad había fracasado»; como ha visto Peter Elmore $(1993,11)$, «la proto-historia de la modernidad urbana en el Perú concluyó en una debacle». 
como obra paradigmática la novela de título homónimo, Una Lima que se va, de José Gálvez (1921). En este sentido, «Palma integra los tiempos y los sucesos de nuestra historia en el universo cerrado de la ciudad antigua, generando la idea de continuidad». ${ }^{20}$ Desde entonces, esa tradición seguiría alimentándose incluso en aquellos autores que plasmaron los orígenes de la transformación urbana y su desarrollo posterior, desde Martín Adán con $\mathrm{La}$ casa de cartón (1928), a los autores de la Generación del Cincuenta, o del neorrealismo urbano, encabezada por Julio Ramón Ribeyro y continuada por narradores como Alfredo Bryce Echenique y Mario Vargas Llosa.

En la continuidad de esa tradición urbana Alonso Cueto es un autor fundamental, con sus novelas ambientadas en la Lima del conflicto armado de los ochenta con Sendero Luminoso y sus devastadoras consecuencias en las décadas posteriores, tales como Grandes miradas (2003), La hora azul (2005), La pasajera (2015), entre las más destacadas. ${ }^{21}$ En esta trayectoria, en la que la Lima del pasado más inmediato ha sido escenario imprescindible de su narrativa, el escritor ha sorprendido con La Perricholi. Reina de Lima por el viraje hacia la novela histórica propiamente dicha, que supone un engarce con la tarea comenzada por Palma un siglo y medio atrás en lo que a la recuperación narrativa de la Colonia se refiere. En ella, construye la gran novela sobre la Lima colonial que el tradicionista había plasmado fragmentariamente en esos textos breves que son las tradiciones. Si bien en las últimas décadas algunos autores han incursionado en esa Lima virreinal, en obras como El llanto en las tinieblas (2002) de Sandro Bossio y Neguijón (2005) de Fernando Iwasaki, el protagonismo con el que se edifica la capital del virreinato en la novela de Cueto la convierte en obra paradigmática en este sentido. A este respecto, en sus páginas se produce la transfiguración de la realidad histórica a través de la cual afloran las imágenes de una Lima sensual, contradictoria, llena de contrastes, pasional, intensa, superficial y profunda, como sus fachadas y sus patios interiores, en conexión indisoluble con la configuración psicológica del propio personaje de Micaela Villegas, que pivota entre su imagen exterior y la configuración más íntima. Así, desde el comienzo de la novela, Cueto fija la mirada en ese contraste definitorio de la ciudad, mediante el cual se manifiesta la doble dimensión de la historia literaria de la urbe antes enunciada, una ciudad en la que conviven aristocracia y pobreza, religiosidad y espíritu mundano, con carrozas y trajes de lujo deambulando al lado de menesterosos:

20 Vidal, 1986, 16.

21 Véase Camacho, 2006; Paradas, 2018. 
Se encontró de pronto con la plaza principal de Lima y le pareció que sus arcos, la catedral, los árboles, las calesas, formaban el conjunto más bello y distinguido, una zona bendecida por la gracia [...] Pero más allá de las gentes vestidas y de las autoridades y de las calesas, veía con claridad las paredes con manchas, los montículos de piedras, las verduras podridas, los olores pestilentes y las gentes en harapos. Había algo de sucio y confuso en ese lujo. Iba a tener que ordenarlo. ${ }^{22}$

En estas líneas surge explícitamente esa Lima como ciudad de la gracia que vieron y poetizaron los modernistas, así como la belleza de la llamada en sus orígenes «la Ciudad de los Reyes», que en la novela aparece —utilizando el clásico recurso de las Crónicas de Indias para la construcción mitificadora de las nuevas ciudades americanas, esto es, la comparación con las grandes ciudades del Viejo Mundo- como «la Roma de América». ${ }^{23}$ Los factores históricos comienzan a desgranarse también desde los primeros capítulos: por ejemplo, se hace referencia al tabaco y el azúcar como «industrias florecientes», se recuerda el terremoto de 1746, o las «epidemias en una ciudad tan insalubre donde se había acumulado tanta basura y desperdicios», en un momento en el que, con la creación del virreinato de Nueva Granada, «el puerto del Callao había perdido importancia». En toda esa contextualización se describe también el carácter de los limeños a través de la palabra «indolencia», y su «poca capacidad de disciplina». ${ }^{24}$

La configuración racial de la ciudad, y la problemática social intrínseca, está también bosquejada desde las primeras páginas de la obra: una ciudad de «algo más de treinta mil habitantes, con mayoría blanca pero con una población negra considerable. Sabía que había más negros que indios y mulatos. Sabía también que las rebeliones indígenas siempre eran posibles». ${ }^{25}$ A lo largo de la novela esa problemática es una constante, pues en esa ciudad llena de nobles, plazas, calesas, señoras engalanadas con esclavos, los blancos «trataban a los pobres, a los negros y a los indígenas como si fueran culpables de serlo. Para ellos ser pobre era una grave falta moral. Sí, pero para Manuel no era así». ${ }^{26}$ Frase que bosqueja la dimensión ilustrada del virrey que veremos más adelante. En esta línea modernizadora, la llegada de Manuel de Amat y Junyent surge en la novela con esta impronta, la de acometer el plan de renovación de la ciudad: «Voy a convertir a Lima en una ciudad elegante, limpia, con alamedas, plazas y fuentes, marcada por la

22 Cueto, 2019, 35-36.

23 Ibidem, 54.

24 Ibidem, 38.

25 Ibidem, 37

26 Ibidem, 209. 
justa sensualidad de la estirpe de los Borbones». ${ }^{27}$ Este objetivo iría acompañado por el florecimiento de la literatura, los famosos cenáculos de escritores congregados desde décadas atrás en torno a la academia del marqués de Castell-dos-Rius, otro virrey catalán de comienzos del siglo XVIII que es recordado en la novela por Cueto para establecer el engarce con la pasión por el teatro de Manuel de Amat: «El teatro era el modo como una ciudad se celebraba. Se celebraba en las multitudes y en la intimidad», ${ }^{28}$ idea que le llevaría a impulsar la tradición teatral con la que «Lima crece, se ilumina». ${ }^{29}$

Asimismo, los recorridos por los espacios emblemáticos de la ciudad son habituales a lo largo de la novela; espacios tales como la Alameda de los Descalzos, en el barrio del Rímac (el de la Perricholi), la Alameda de los Bobos, el Puente de Piedra, el Puente Balta, la Pampa de Amancaes o el Cerro San Cristóbal, destacando las grandes calzadas por las que circulaban las carrozas: «Había querido hacer una ciudad para que ella y su hijo pudieran vivir siempre. El Paseo de Aguas, la Plaza de Acho, la higiene y la salud de las calles, la reconstrucción de las plazas, la remodelación del Coliseo de Comedias, la Iglesia de las Nazarenas, las nuevas acequias, las fuentes de agua». ${ }^{30}$ Una reforma urbana integral que da como resultado el hecho de que «Lima era una ciudad llena de entretenimientos. Las cafeterías, los teatros, los mercados, los lugares de venta». ${ }^{31}$ Por ello la palabra más repetida para definirla es la «novedad», y se insiste en las influencias recibidas de Europa, especialmente de Italia y sobre todo de Francia.

Ante tan amplia configuración urbana, para un análisis crítico de la misma conviene distinguir dos conceptos básicos cuando nos referimos al eje literatura y ciudad: el de «teatro urbano» en su diferencia con el de «escenario urbano». El primero se refiere a los seres que pueblan la ciudad, y contiene en su significación tanto el nivel de artificio que el espacio urbano implica de forma consubstancial, como su dimensión ética. ${ }^{32}$ Se diferencia del segundo, el escenario urbano, en que este se refiere a la configuración física y material de la urbe.

27 Ibidem, 38.

28 Ibidem, 39.

29 Ibidem, 273.

30 Ibidem, 219.

31 Ibidem, 224.

32 Utilizo el concepto en el sentido apuntado por Cañas, 1994, 10. En sus palabras, esta noción «connota un nivel de artificio que es consubstancial a la idea de ciudad en general; y estará, por un lado, más ligado a una mirada de orden ético y, por el otro, es un concepto recurrente en la mirada urbana moderna». 


\section{La Perricholi. Reina de Lima, síntesis del teatro urbano colonial}

La novela desarrolla el concepto de teatro urbano de forma paradigmática en lo relativo a su definición, tanto en lo que atañe a la noción de artificio como a su referida dimensión ética. Así, vemos cómo se construye progresivamente dicho teatro desde el comienzo de la novela, en fragmentos en los que la descripción objetiva de inmediato da paso a la visión problematizadora del heterogéneo entramado social limeño:

las pregoneras y los vendedores y los curas y los vagabundos, pero sobre todo las condesas y los condes, los caballeros de la Orden de Santiago, las marquesas y los marqueses que se subían a las carrozas y que miraban desde sus ventanas, con la distancia altiva de su piel de marfil, con los círculos negros en la cara que llamaban chiqueadores, y con sus sombreros de plumas afiladas, y también los oficiales con sus uniformes, los comerciantes con sus papayas y magos, pero sobre todo los religiosos que caminaban con la cabeza gacha, con sus hábitos dominicos de negro y blanco, aferrados a sus crucifijos. ${ }^{33}$

Este entramado se edifica como teatro urbano en el que cada descripción contiene el contraste, transmitido de las más diversas formas posibles. Así, en estas líneas aparece a través de los olores de la ciudad, mezcla de humo, grasa frita y perfumes que se aglutinan y funden con el elemento natural más característico y tipificador de la imagen de Lima, la neblina: «Muchas vendedoras se vestían con trajes coloridos. Cuerpos esbeltos y oscuros en telas limpias, los brazos extendidos, con frutas o tamales en las manos. Una demostración de la modesta lujuria de los pobres. El aire de humo y perfumes y grasa frita, de sahumerios y gritos ardía en la neblina». ${ }^{34}$ Esos contrastes se encuentran plasmados en ocasiones de forma solapada o sugerida, y en otras explícitamente, a modo de mal endémico, como en este diálogo: «-Mírelos a todos. Tan bien vestidos junto a otros que llevan harapos. -Contrastes. No nos libramos de los contrastes». ${ }^{35}$

Más allá de la noción teórica de teatro urbano, se encuentra también en la novela la del nivel performativo de ciudad teatral que se produjo en el siglo XVIII con el impulso que a los teatros dio el virrey Amat; un espíritu teatral que en la novela aparece vinculado con la esencia misma de la ciudad: «Lima es una ciudad de gente de teatro, siempre fue así [...] El primer Corral de Comedias de la ciudad fue inaugurado por Juan Gutiérrez

33 Cueto, 2019, 54.

34 Ibidem, 62.

35 Ibidem, 283. 
Molina hace ya más de siglo y medio, en $1604 » .{ }^{36}$ Esta ciudad de teatro en ese momento de la historia se tiñe, como ya hemos visto, de afrancesamiento: «Hacemos obras de Racine y Corneille [...] Hacemos Ifigenia, Fedra $y$ Berenice. Eso hacemos. La elite de Lima que se había aficionado al teatro prefiere autores franceses por sobre los españoles». ${ }^{37}$ Es más, incluso la idea teatral adquiere en determinado momento de la novela la dimensión calderoniana de La vida es sueño: «La vida es un teatro y un teatro es todas las vidas» ${ }^{38} \mathrm{y}$ «el teatro sigue cuando después ven a los esclavos ir a las tabernas para conseguir sal, manteca, vinagre, mientras ellos observan ese cortejo de pobres a la distancia». ${ }^{39}$

Por último, es preciso reparar en que la novela establece una mirada actual sobre la ciudad del pasado en varios sentidos, uno de los cuales se evidencia en la idea baudelairiana, desarrollada hasta la actualidad, del caminante que en el deambular conoce y se apropia de la ciudad. Con reminiscencias del flâneur, Cueto utiliza la idea en estas líneas en las que teatro y escenario urbano se funden, tanto como los opuestos que identifican a la ciudad:

Caminar era su modo de conocerla, de amarla, de cortejarla, de conquistar sus calles y sus sonidos, asimilarlos para que no se le fueran nunca [...] El teatro de la calle y la variedad del mundo. Lima era un escenario de gritos y también de rumores entre dientes. Alaridos de clérigos rezando, susurros entre dientes. Alaridos de clérigos rezando, susurros de amantes furtivos y maledicencias sobre el sudor y el perfume. ${ }^{40}$

Lima convertida en escenario para la representación del teatro del mundo, en referencia a la confluencia de tan diversas razas como se dio en su seno, aparece en la novela delineada en todos sus contornos físicos que, indefectiblemente, son reflejo constante de los humanos.

\section{Lima como escenario urbano de La Perricholi}

Presidida por el sonido de las campanas, que aflora en la novela como una especie de lenguaje de la ciudad, ${ }^{41}$ las descripciones del escenario,

$36 \quad$ Ibidem, 66.

37 Ibidem, 67.

38 Ibidem, 358.

39 Ibidem, 359.

40 Ibidem, 60-61.

41 «Por su oráculo noble y prestigioso, por el sonido cargado de misterio de su vieja voz espiritual, a Lima hay que traducirla, por lo tanto, como la ciudad que habla». Miró Quesada, 1958, 17. 
siempre en fusión con su teatro diario, revelan la intencionalidad del autor de edificar la imagen viva de la Lima colonial:

\begin{abstract}
los ruidos y los olores, los perfumes ajenos, los sonidos pestilentes de aguas de desecho y de bosta de mulas, los humos de brasas y de ceniza, los sonidos de pregoneras, de ruedas de carruajes, de gritos y carcajadas en las plazas, los olores de sahumerios y de las brasas de carnes de cerdo y las imágenes lentas de los mendigos hundidos en sus harapos, y de los caballos de cabeza alzada y de gualdrapas y la superficie de paredes amarillas, rosadas, azules, paredes frías, cubiertas de polvo, las paredes de la ciudad. $^{42}$
\end{abstract}

Este párrafo hila la historia literaria de la ciudad, pues dialoga con la perspectiva crítica que desde los siglos coloniales puso el punto de mira en las imágenes más desmitificadoras de la ciudad, así, por ejemplo, con las de un autor que aparece hacia el final de la novela, Esteban de Terralla y Landa. Llegado al Perú en 1787, este andaluz escribió el conocido poema titulado Lima por dentro y fuera, en el que, cáustico y socarrón, denunció el materialismo imperante en las relaciones humanas y subrayó los aspectos más negativos de la imagen de la ciudad: «Tú en ver la ciudad de Lima/ estás amigo resuelto,/ más yo con mi inteligencia/ quiero disuadirte de ello/ [...]/ Lo primero que verás/ será un asqueroso suelo,/ de inmundas putrefacciones,/ y de corrupciones lleno./ Hay acequias apestadas,/ caños rotos, basureros,/ muladares, y cloacas,/ con mil montones de cieno». ${ }^{43}$

La fijación de esta imagen recogida por Cueto sirve para abundar en el proceso de renovación que acometería el virrey Amat, del que se habla a lo largo de toda la novela: realizar el Paseo de Aguas, «promover los cafés en la ciudad» ${ }^{44} \mathrm{y}$, sobre todo, utilizar el modelo francés: «Durante sus años en París había entrado varias veces al Café de la Régence. Allí se habían encontrado Diderot y Rousseau en 1742. Allí se jugaban grandes partidas de ajedrez que embelesaban al público. Era un sitio de lujo. En Lima debía haber algo así». ${ }^{45}$ En determinado momento de la obra, el objetivo de Amat se explicita en estas líneas en las que se enfoca el cambio de mentalidad del nuevo virrey:

Lo que quiero es hacer una gran ciudad — dijo, alzando la copa-. Lima, la gran ciudad. La gran universidad, el gran paseo, las calles más bellas. Versalles o Roma. Algo

42 Cueto, 2019, 60.

43 Terralla y Landa, 1838, 13-16.

44 Cueto, 2019, 115.

45 Ibidem, 115. 
así. Me interesa mucho la biblioteca en la Universidad de San Marcos, por ejemplo. Y odio la tristeza y la solemnidad de los limeños, y su religiosidad exagerada y esa costumbre de poner al Cristo en la cama con ademán de enfermo que tienen algunas iglesias. ${ }^{46}$ sombras:

Pero la construcción del escenario siempre pivota entre luces y

Entraba en esas calles cargadas de perfume y de pregones, de sonidos de ruedas y mulas, de olores pestilentes y trajes luminosos y de religiosos acorazados por el hábito negro y blanco, avanzando entre hilos curvados de humo. Los balcones de madera fina, hecha de huecos minúsculos por donde unos ojos apasionados y secretos miraban el ruido y los colores del universo. Fiestas y silencios, perfumes y pestilencias, el arco iris y las sombras: Lima. ${ }^{47}$

Asimismo, Cueto hace emerger también la tradicional visión centralista de Lima en su no menos secular divorcio con el resto del país, de modo que las tres geografías del Perú, selva, sierra y costa, son visualizadas desde Lima y desde sus casonas: «Allí está nuestra ciudad — le decía_- A un lado los Andes, y al otro, el mar. Y al fondo, entrando por los Andes, la gran selva». Frente a esas geografías, el hijo de Micaela y del virrey, prorrumpe en la frase idealizadora: «Qué grandeza hay aquí, madre». ${ }^{48}$ Como he avanzado, esta grandeza fue creada literariamente por los autores del Novecientos desde la nostalgia del bien perdido, configurando el tópico de «la Lima que se va». ${ }^{49}$ Cueto da continuidad a este tópico en fragmentos como el siguiente, fiel reflejo de la mitificación de Lima como hortus clausum virreinal, que contiene todos los motivos recurrentes de su configuración literaria; léase, la melancolía asociada al cielo gris y la llovizna, la belleza de sus casas y sus mujeres, los árboles, el sonido apacible de las aguas, etc., en suma, una suerte de locus amoenus que desde los textos coloniales aparece identificando a Lima como paraíso terrenal:

46 Ibidem, 138.

47 Ibidem, 60. Retomando la idea de continuidad, conviene recordar este fragmento de Miró Quesada (1958, 42-43) sobre los balcones y la imagen urbana: «Al lado de los balcones fueron multiplicándose, como otra de las características arquitectónicas de Lima, los vivaces azulejos. Los conventos primero, los templos luego y las casas después, se fueron engalanando con esos barros vidriados de colores, en que se unía la gracia de la ciudad con el refulgente sol de Andalucía y el abolengo artístico de las tierras morunas».

48 Ibidem, 210.

49 La Lima cuyo presente, en palabras de Julio Ortega (1986, 27), «convierte al futuro en un fantasma del pasado». 
Lima, Lima. Aquí está el cielo gris y la melancolía y las lloviznas y el discreto encanto de las mujeres. Y las flores amarillas de la Pampa de Amancaes. Y los balcones y las casas y las plazas con las piletas de agua tranquila, y el descanso de las aves en los árboles. Y el mar, tan cerca, con esa sabiduría de su dramatismo. [...] Una ciudad con la miel en el aire, el embrujo de su grisura, hecha para hacer creer a todos los visitantes de sus precarias glorias. Aquí había muchas razones para pelear, entre ellas el apego por la luz del teatro en esta ciudad de la neblina. Luchar hacia la luz. ${ }^{50}$

Esta última imagen urbana, presidida y determinada por su atípico cielo, es motivo reiterado en la novela, como lo es en la historia literaria de la ciudad, y sirve a Cueto como metáfora para intensificar la idea de renovación instaurada en el XVIII: «Soy de Lima y el sol no es lo mío. Nosotras mismas tenemos que hacer la luz [...] — Vamos a iluminar toda la ciudad de Lima, Miquita». ${ }^{51}$ Se trata del escenario de una Lima que concentra lo que es el Perú, como dice la célebre aseveración atribuida a Abraham Valdelomar, emblema del secular centralismo de la capital: «El Perú es Lima, Lima es el Jirón de la Unión, el Jirón de la Unión es el Palais Concert y el Palais Concert, soy yo». ${ }^{52}$ En ocasiones, tras hacer historia de una calle como la de Trujillo, o la calle de Desamparados, teatro y escenario adquieren otra dimensión, en este fragmento en el que la propia ciudad aparece personificada a través de la mirada de Micaela:

A Micaela le parecía que las casas eran seres vivos. Las ventanas eran ojos de muchas pupilas y las puertas eran grandes bocas que aceptaban solo a quienes era [sic] dignos de ellas, y las paredes eran la piel lustrosa y húmeda de sus habitantes. Las casas presenciaban el espectáculo de la calle, escuchaban todo lo que decía y veían todo lo que pasaba. Luego lo asimilaban y lo guardaban en los intersticios de adobe, entre las paredes, para quien quisiera escucharlo y verlo desde allí muchas veces más. Y con las calles ocurría lo mismo. Las calles sabían de todo lo que había ocurrido allí. ${ }^{53}$

La ciudad, escenario y teatro urbano, se convierte aquí en el propio concurrente al espectáculo que se produce en sus calles, que acumulan y retienen su historia. Una visión nuevamente actual sobre la ciudad histórica.

50 Cueto, 2019, 208-209.

51 Ibidem, 271.

52 En este mismo sentido, escribe Sánchez (1988 [1951], 34): «La historia de la cultura colonial no se explica sin la actividad de Lima, un oasis en medio del desierto». Este secular centralismo capitalino - por otra parte característico en el ciclo de las fundaciones de las ciudades latinoamericanas - ha determinado los procesos a través de los cuales la historia de la literatura peruana refleja la evolución de una sociedad herida por su profunda segmentación.

53 Cueto, 2019, 62. 


\section{La historia en la literatura}

Según Carlos García Gual, la novela histórica debe combinar tres elementos fundamentales: «documentación e incluso erudición suficiente para reconstruir el marco histórico y las figuras evocadas; buena dosis de fantasía para dar vida a la ficción verosímil y patética, y un claro estilo narrativo». ${ }^{54}$ Qué duda cabe que Alonso Cueto concentra los tres elementos en su novela, pues la documentación histórica es evidente como veremos a continuación; el estilo narrativo que vivifica la escena de la Lima dieciochesca es un rasgo excepcional de la prosa; y la portentosa dosis de fantasía coadyuva a ese fin vivificador de la historia. Un fragmento de la «Nota del autor» final zanja la perspectiva literaria aplicada a la historia en la novela:

Supe tiempo después que en realidad la Perricholi jamás había vivido en esa casa de la Quinta de la Presa a la que habíamos ido. La historia ha puesto en duda que ella hubiera caminado por los salones de ese palacio de los Borbones, mucho menos que se hubiera bañado en esa tina. Pero mi imaginación ya la había visto. Luego aparecieron sus muchos rostros en las películas, las series, las biografías y las novelas. En todos ellos la veía con modificaciones, pero con rasgos comunes. ${ }^{55}$

Desde esta perspectiva fijada por Cueto para penetrar en la ficcionalización de la historia en La Perricholi. Reina de Lima, cabe recordar la terminología propuesta por Paul Ricoeur, la «historización de la ficción», ${ }^{56}$ con la que se refiere a la utilización de estrategias de la escritura historicista en los textos literarios, tales como citación de fechas, de lugares, de personajes históricos, etc. Estas estrategias son un recurso fundamental en la novela de Cueto para simular que el texto literario narra las cosas como si efectivamente hubieran ocurrido, pero también para incidir en la potencialidad de lo posible. ${ }^{57}$ Sin duda, algunas ocurrieron y otras pudieron haber ocurrido. Sin afán de entrar en la debatida cuestión sobre las semejanzas y diferencias entre el historiador y el novelista en el tratamiento del material histórico, sí es importante constatar que la presente novela entra en el territorio compartido con el discurso histórico en lo relativo al ofrecimiento de

54 García Gual, 2002, 11.

55 Cueto, 2019, 441-442.

56 Ricoeur, 2009, 913.

57 «Una de las funciones de la ficción, unida a la historia, es la de liberar retrospectivamente ciertas posibilidades no efectuadas del pasado histórico [...] Lo que "habría podido acontecer" —lo verosímil, según Aristóteles- recubre a la vez las potencialidades del pasado "real" y los posibles "irreales" de la pura ficción». Ibidem, 916. 
un testimonio de la época, de los ideales y del entorno histórico con el que construye un imaginario social. Y en este orden de cosas, se trata de un discurso literario que es una proyección del mundo limeño virreinal en la que Cueto propone su personal retrato de la sociedad y de la vida de una ciudad que, en última instancia, resulta fundamental para la comprensión no solo del mundo en el que la trama se desenvuelve, de acuerdo con sus principios éticos, sino del propio presente de Lima y del Perú. En este sentido, se patentiza en todo momento que el universo de la novela, aunque se remonte siglos atrás, es, en el fondo, el de su autor.

Para penetrar en ese universo histórico pasado por el tamiz de la ficción, recordemos que, según Lukács, una novela es considerada histórica cuando hay una voluntad de captar la singularidad histórica de las personas y situaciones plasmadas. ${ }^{58} \mathrm{Y}$ que sus rasgos artísticos, fijados originalmente en la narrativa de Walter Scott, son la extensa descripción de las costumbres y de las circunstancias que rodean los acontecimientos, el carácter dramático de la acción y el destacado papel del diálogo en la novela. ${ }^{59}$ Todos y cada uno de estos rasgos se concentran en la obra de Cueto. Por una parte, la carga dramática se desarrolla a través de los conflictos suscitados por las pasiones humanas (envidia, celos, lujuria, engaño, etc.), siendo la relación entre el virrey y Micaela Villegas el núcleo del conflicto pasional que hace que esa dimensión dramática se intensifique. Por otra parte, todo ello se crea siempre a través de una destacada presencia de los diálogos en estilo directo y dentro de una envoltura de acontecimientos históricos que se nos dan en la forma de una construcción estéticamente ordenada de situaciones documentables a caballo entre la ficción y la referencialidad; construcción en la que opera la subjetividad del autor para la recreación de una época y de sus elementos constitutivos y simbólicos. Esta abarca en la novela de Cueto tanto a personajes como a los acontecimientos históricos del siglo XVIII y comienzos del XIX. Comencemos por los primeros.

\section{Figuras históricas y personajes históricos novelados}

Para introducirnos en la nómina de personajes que aparecen en las páginas de la novela, conviene hacer la distinción fijada en este epígrafe, puesto que por un lado encontramos figuras históricas que forman parte de

58 Lukács, 1966, 16.

59 Ibidem, 30. 
los factores configuradores del contexto y que no entran en la trama argumental, y por otro aparecen figuras históricas como personajes novelados que, o la protagonizan, o bien funcionan como personajes secundarios. Así, a lo largo de los capítulos encontramos en ese entorno contextual figuras históricas que pueden ser del siglo anterior, tales como los autores que configuran las lecturas de Micaela, por ejemplo, Juan Ruiz de Alarcón, Lope de Vega o Calderón de la Barca, que aparece mencionado con la mítica frase de La vida es sueño, «apurar cielos pretendo» ${ }^{60}$ o figuras del Setecientos que fueron muy destacadas en lo que atañe a las grandes expediciones científicas que determinaron el escenario ilustrado de la Hispanoamérica dieciochesca. Surgen así en varios momentos los célebres navegantes españoles Jorge Juan y Antonio de Ulloa, a través de los cuales Cueto introduce la conflictiva cuestión de la raza a partir de la palabra mestiza. Esta aparece como insulto constante a Micaela y como objeto de reflexión de los famosos marinos, cuyo viaje al Perú para la medición del grado de la tierra dio lugar a la conocida obra Noticias secretas de América, también presente en la novela. En la nómina de viajeros científicos no podía faltar Alexander von Humboldt y su viaje con Aimé Bonpland, determinante para la América de la época, en los tiempos preindependentistas:

Habían estado en el río Magdalena y en el volcán Pichincha. Grandes y bellas tierras, con mucho que descubrir, dijo apenas se instaló en el Callao, donde se dispuso a medir la temperatura del Océano Pacífico. También, según explicó a algunos limeños, había estudiado las propiedades del guano como fertilizante. ${ }^{61}$

También el navegante inglés James Cook aparece en la novela con la misión que le fue encomendada por la Royal Society de Londres en 1768, a través de la cual Cueto introduce la relevante cuestión geográfica que marcó los siglos coloniales, en cuyo transcurso los contornos de la tierra se seguían dilucidando en los mapas: «Lo han comisionado para encontrar las huellas del tránsito de Venus sobre el sol. Ha ido por el Cabo de Hornos (usted sabrá que se llama así por el poblado holandés de Hoorns y por su forma de cuerno), es decir, el punto más austral del continente americano». ${ }^{62}$ Con esta figura, como con las anteriores, el conocimiento científico, que supuso un redescubrimiento de América desde los nuevos ideales ilustrados de la época, aparece en la novela como eje fundamental: «De allí fue a explorar

\footnotetext{
60 Cueto, 2019, 280

61 Ibidem, 418.

62 Ibidem, 184
} 
la existencia del continente más austral, vea usted: Terra Australis, una tierra que el español Váez de Torres ya había descubierto en 1606. Pero Cook fue el segundo europeo en llegar a Nueva Zelanda [...] es considerado un héroe de la ciencia en Inglaterra». ${ }^{63}$

En esta misma línea ilustrada, Cueto menciona a Voltaire y su obra Cándido, con el fin de insistir en el afrancesamiento del virrey y en la absorción de las nuevas ideas: «—Un gran escritor. Un pensador. Pero le diré que este hombre entendió lo que pasa aquí, en América. Aquí en América hay gente extraordinaria [...]». ${ }^{64}$ Con esta última frase, puesta en boca del virrey, la novela incorpora una cuestión de especial relevancia, la defensa de los indígenas americanos por parte de una autoridad monárquica, sin duda una manifestación de americanismo en las puertas de la Emancipación que Cueto plasma sin escamotear su problemática intrínseca:

Es gente de valor. No se olvide que esta fue la cuna de muchas grandes civilizaciones. Pero son muchas culturas distintas que confluyen, para bien y para mal. Todos son muy distintos y cada uno va por su lado. Tenemos que darles un ideal común, algo que los una. Y mire lo que son capaces de hacer estos artistas que hay aquí. ${ }^{65}$

El concepto de heterogeneidad cultural desarrollado por el crítico Antonio Cornejo Polar encuentra en este párrafo una formulación paradigmática, en tanto en cuanto la confluencia de culturas que se dio en el Perú, lejos de plantearse en la forma armónica, homogeneizante y desproblematizadora que se pretendió a través de las teorías sobre el mestizaje cultural, se plasma en toda la conflictividad que contiene y que era el gran escollo de esta sociedad. ${ }^{66}$ Qué duda cabe que en esta formulación se encuentra la mirada actual de un escritor que recupera el pasado para leer la problemática endémica que, con evidentes matices, pervive en el Perú del siglo XXI: la discriminación por clase social y color de la piel, fundamentalmente. Frente a ella, la novela pone en el centro de la escena aquello que la Perricholi

63 Ibidem, 184-185.

64 Ibidem, 111.

65 Idem.

66 Véase Cornejo Polar 1994; 1996; 1998. Cornejo Polar vio en los conceptos de mestizaje y transculturación la tendencia a la definición de una realidad desproblematizada y armoniosa. Frente a ellos, mediante el concepto de heterogeneidad — como ha explicado Rovira (1999, 109)—, Cornejo «se afincará en una realidad cultural y literaria problematizada y conflictiva, para considerarla centro de cualquier visión que quiera dar cuenta de los procesos y las relaciones de la literatura en el marco de una sociedad concreta. La perspectiva contraria, todo lo que pretenda debilitar el conflicto discursivo (entre literatura hegemónica, literatura popular, literaturas indígenas) será una suerte de mistificación teórica». 
significa: la posibilidad del cambio y el progreso personal por el esfuerzo y la valía individual.

La cuestión es que esta expresión de sentimiento americanista se formula de diversos modos a lo largo de la novela, así, por ejemplo, al hablar sobre manifestaciones artísticas: «-Imagínese. Eso lo hicieron artesanos de aquí. Y nada que envidiarle a los que vienen de Europa ${ }^{67}$. A lo que, de inmediato, sucede de nuevo la cuestión racial y los prejuicios seculares:

— ¿Y por qué son tan sucias y desordenadas estas gentes? — No son así. Se equivoca. Lo que pasa es que han sido vapuleadas por la historia. Han perdido mucho, se lo han quitado. Pero ahora tenemos que retomar un culto a la unidad. Un culto al orden. Lo más importante es que todo parezca en orden [...] Quiero que amen su ciudad y su rey. Si han perdido un imperio, vamos a ofrecerles otro. ${ }^{68}$

Ante tal panorama, se reitera en varias ocasiones la necesidad de aportar una idea de unidad, que tiene su punto de irradiación, como ocurre en todo el proceso de la conquista de América, en la ciudad, centro de poder que expande su dominio hacia un territorio socialmente heterogéneo: «Llevaba casi quince años en Lima, pardiez. En ese tiempo, había logrado dar un sentido de unidad al imperio. Se lo había repetido desde el primer día. Todo imperio tiene que crear ciudades con centros desde los cuales sentir y celebrar su inmensidad». ${ }^{69}$

Siguiendo con el repaso de las figuras históricas que aparecen en la novela, si pasamos de las foráneas a las peruanas, vemos desfilar a figuras fundamentales de la cultural limeña como Santa Rosa (que protagonizó el siglo XVII peruano tanto como la Perricholi el XVIII), Mariquita Castellanos, el mencionado poeta Esteban de Terralla y Landa, y personajes determinantes de la inminente Independencia como Hipólito Unanue, quien «fundó la Sociedad de Amantes del País [...]. El periódico bisemanal, el Mercurio Peruano, empezó a publicarse en 1790. Allí Micaela leía los artículos de Unanue, firmados con el nombre de "Aristio", en los que se refería a algo nuevo, algo que ella no había escuchado: "Una idea general del Perú" »; $;^{70}$ el poeta Mariano Melgar, que murió fusilado tras una de las batallas de la Independencia, y que aparece como «un joven poeta arequipeño» que escribió la Oda a la libertad, que «es enamorado y revolucionario». ${ }^{71}$

67 Cueto, 2019, 111.

68 Ibidem, 112.

69 Ibidem, 279.

70 Ibidem, 355-356.

71 Ibidem, 425. 
Entre todos, me interesa detenerme en una figura que nos traslada de la nómina de personajes históricos meramente contextuales a la de los personajes que Cueto ficcionaliza; una figura que además los escritores peruanos ya habían convertido en uno de los personajes literarios más fascinantes de la Colonia. Se trata de Santiago de Cárdenas, que pasó a la historia por la invención de un artilugio para volar y que protagonizó uno de los juicios más sonados de la Colonia. Cueto le dedica un amplio espacio ${ }^{72}$ que le permite describir Lima como «una tierra de soñadores»: «Fue cuando supo el pedido del señor Santiago de Cárdenas a quien algunos empezaron a llamar "el pajarero", y "el volador". El señor Cárdenas había estado planificando un artefacto diseñado para volar, inspirado en el vuelo del cóndor andino». ${ }^{73}$ Con la introducción de este personaje, y de ambas palabras para designarle (pajarero y volador), Cueto establece una línea de continuidad y un diálogo intertextual con Ricardo Palma y con Julio Ramón Ribeyro, pues si el primero le dedicó la tradición titulada «Santiago el volador» (perteneciente a la tercera serie de las Tradiciones peruanas), Ribeyro escribió una obra teatral, Santiago el pajarero (1959).

En la tradición palmiana, ubicada en la Lima del siglo XVIII durante el mandato del virrey Amat, el tradicionista relató la historia de Santiago de Cárdenas, quien se propuso llevar a cabo el prodigioso proyecto de volar como los cóndores, un sueño que le valió el escarnio general de su pueblo y la humillación de las autoridades. Así concluyó Palma su historia:

Concluyamos. Santiago de Cárdenas aspiró a inmortalizarse, realizando acaso el más portentoso de los descubrimientos, y, ¡miseria humana!, su nombre vive sólo en los fastos titiritescos de Lima.

Hasta después de muerto lo persigue la rechifla popular.

El destino tiene ironías atroces. ${ }^{74}$

El relato de Palma, pretendidamente objetivado en documentos fidedignos como es el manuscrito que lleva por título Nuevo sistema de navegación por los aires, por Santiago de Cárdenas, natural de Lima en el Perú ${ }^{75}$ fue reformulado en la obra de Ribeyro conforme al interés del escritor que, recuperando la figura ya legendaria de Santiago de Cárdenas,

72 Ibidem, 101-105.

73 Ibidem, 101.

74 Palma, 1894, 122.

75 Palma informa de que «el manuscrito se encontraba inédito en la Biblioteca Nacional del Perú. En 1878 se publicó en Valparaíso, por la casa editorial de Jover, en un tomo de 230 páginas en 8. , con cuatro grabados, sirviendo de prólogo este artículo. (N. del A.)». Idem. 
y reconstruyendo el ambiente de la Lima colonial dieciochesca, consiguió realizar una crítica al dogmatismo histórico frente a cualquier brote de genialidad, en este caso representada en el artilugio inventado para volar. Frente a este visionario personaje, Ribeyro — siguiendo esquemas brechtianos-, creó un mundo académico obsoleto y mediocre que, unido a la frívola sociedad del XVIII, hacen trizas un sueño, el de volar, que al fin y al cabo simboliza el progreso, la modernidad y el individualismo creador. En este sentido, Eduardo Hopkins destacó en el planteamiento ideológico de esta obra la puesta en juego de «la lucha entre lo nuevo y los prejuicios conservadores; a esto debe sumarse la orientación social de su crítica y la sugestiva recreación del mundo de la época». ${ }^{76}$ Si Ribeyro creó, con su Santiago el pajarero, un nuevo capítulo dieciochesco para los anales de la literatura peruana, Cueto es un nuevo eslabón en la recreación del personaje que, en su caso, marca una diferencia, pues lo instrumentaliza para aportar nuevas aristas al personaje del virrey, quien en principio apoya el proyecto de Cárdenas porque «sentía pasión por los soñadores» ${ }^{77}$ Asimismo, en la novela se recrea, como en la obra de Ribeyro, el choque entre el personaje y una sociedad superficial, cruel y soez, que apedrea a Santiago cuando dice no estar preparado todavía para volar y lo convierte en escarnio de la plaza pública.

Por último, en lo que se refiere a personajes históricos transmutados por la ficción, los dos protagonistas de la historia, el virrey y la Perricholi, ocupan el lugar central. El primero aparece en la novela convertido en persona de carne y hueso, un hombre poliédrico y complejo que vivió la llegada al virreinato del Perú desde la Capitanía General de Chile, y la asunción del cargo, con la impronta idealista de la transformación que se ha ido desgranando en estas páginas. Lejos de ofrecer una imagen unívoca del virrey, Cueto construye a un ser vulnerable, con todas las inseguridades de un hombre entrado en años, que vive una profunda soledad tanto en lo que atañe a la vida en un remoto espacio desconocido, como en lo personal, y que, por otra parte, se enfrentó a una sociedad criolla muy conservadora, jerárquica y racista, incapaz de poder bendecir una relación absolutamente reprobable para la época como es la que mantuvo con la Perricholi. Así se describe su llegada al virreinato: «Estaba entrando a la tierra de la gran civilización de los incas, que debía respetar para dominarla mejor. Debía entrar allí con toda solemnidad, como el representante del rey del más grande

76 Hopkins, 1984, 129. He desarrollado un análisis de esta obra de Ribeyro en Valero, 2015.

77 Cueto, 2019, 101. 
imperio del mundo por obra y gracia de nuestro señor». ${ }^{78}$ Abundando en todos sus relieves, al tiempo que se le describe como gran señor, se le aplica el calificativo de $«$ Sonso» ${ }^{79}$ y otros muchos que inciden en los contrastes de la personalidad. En este sentido, aparece en numerosas ocasiones ante la Perricholi con una imagen un tanto esperpéntica, con su peluca, su banda, sus insignias, su cara empolvada, en suma, como un ser humano a veces ridículo, escondido tras todo el artificio propio de la época, y dominado por Micaela Villegas.

Frente a esta imagen, que es la que aparece en los cuadros novelescos donde se construye el espacio de la intimidad de la pareja, surge el perfil del hombre valiente que se opuso a los prejuicios de aquella sociedad elitista conformada por la aristocracia colonial, incluso en su problemática más compleja, la de la cuestión racial. Para esa construcción que recorre la novela y que, como veremos, se cimienta especialmente a partir de la introducción de los acontecimientos históricos, Cueto llega a poner en palabras del virrey la frase «no hay razas inferiores ni superiores». ${ }^{80}$ Esta aseveración encaja con la alabanza que hemos visto realizar al virrey en otros momentos hacia los indígenas, enarbolando su valor o ensalzando la belleza de sus producciones artísticas. En estos sentidos, Cueto realiza una recreación literaria del personaje edificada sobre la base histórica según la cual Amat fue un hombre ilustrado, que se opuso a la Inquisición y al maltrato a supuestos infieles. Y desde esa dimensión ilustrada del virrey, el novelista delinea libremente al personaje como un hombre moderno, contrario al racismo y la discriminación que enarbolaba la nobleza criolla.

En lo que respecta a la Perricholi, Cueto también construye al personaje en toda su complejidad, recorriendo toda una vida de éxitos tanto como actriz primero, como en su calidad de empresaria teatral más tarde, y plasmando toda su valentía ante tal sociedad. En su empeño por recuperar el honor familiar perdido tras la ruina de su padre, vemos a una mujer carismática que cristaliza, desafiante, todo un discurso reivindicativo tanto sobre el lugar de la mujer en el mundo, a través de su libertad y su carácter autónomo, como sobre su mestizaje, sin escamotear el sufrimiento ante la marginación y el racismo, que queda en la esfera de la intimidad. En ese sentido, Cueto presenta a una Micaela Villegas conscientemente escandalosa, inteligente y calculadora, vehemente y caprichosa; una mujer cuyo

$$
\begin{array}{ll}
78 & \text { Ibidem, } 35 . \\
79 & \text { Ibidem, } 43 \\
80 & \text { Ibidem, } 38 .
\end{array}
$$


embrujo no solo estaba en su belleza sino en la gracia que desprendía en todos sus gestos e inteligencia, que tenía un gran sentido práctico de la vida y que al tiempo era religiosa y devota. También a través de ella Cueto realiza una actualización de la historia en varias dimensiones directamente relacionadas con sus acciones: influyó profundamente en su tiempo, revolucionó las costumbres de la época y se atrevió a impugnar y enfrentar los grandes dogmas y pilares del orden jerárquico de la sociedad de su tiempo.

La desigualdad y la discriminación se configuran, por tanto, como los dos caballos de batalla de ambos personajes que, con todas sus diferencias, aparecen unidos no solo por la relación amorosa — siempre descrita en los límites entre el erotismo y el amor-sino por dichos ideales.

\section{Situaciones y acontecimientos históricos}

La novela recrea un siglo que es especialmente fecundo en acontecimientos, que el novelista introduce en la obra al tiempo que contextualiza espacios, símbolos, emblemas, etc. En numerosas ocasiones, estos acontecimientos no solo forman parte de la ambientación contextual, sino que son instrumentalizados para contornear los perfiles literarios de los personajes novelescos. Un primer ejemplo significativo en este sentido se encuentra en la referencia a las murallas de la ciudad: «-Felizmente están las murallas del duque de la Palata. Nos van a proteger de los piratas, los corsarios y los bandoleros». ${ }^{81}$ Recordemos que la ciudad se encontraba circundada, desde el año 1685, por las murallas que marcaban no solo sus límites, sino también su fisonomía de reducto espiritual de elite. Son, de hecho, un símbolo principal de la Lima virreinal, que aparece como motivo recurrente a lo largo de la historia de la literatura peruana para imprimir el carácter elitista a la urbe. Sin embargo, Cueto realiza con ellas la misma operación que hemos visto en relación con otros elementos y personajes, en este caso, utiliza la imagen urbana para metaforizar la soledad del virrey: «-Qué bellas mujeres en esta ciudad. Una ciudad amurallada. Y yo un hombre amurallado...». ${ }^{82}$

En relación directa con las murallas, la novela incorpora también los orígenes del proceso migratorio de la sierra a la ciudad, que sería su elemento transformador a partir de mediados del siglo XX:

81 Ibidem, 112.

82 Ibidem, 113. 
- Tanta gente en la plaza. No sé qué hacer con tanto comerciante. Por un lado ensucian todo. Por el otro, tienen derecho de vender sus cosas. Y cada día vienen más de la sierra para vender.

—En el censo de comienzos de siglo se decía que éramos treinta mil, Su Excelencia. Pero le aseguro que ahora somos cien mil aquí, en Lima. ${ }^{83}$

Este proceso está íntimamente vinculado a la cuestión del mestizaje que aparece como uno de los distintos ejes de la novela y que, en ocasiones, adquiere los contornos de ese otro concepto utilizado para definir el proceso de mutación de las culturas en contacto en Hispanoamérica, esto es, la transculturación. ${ }^{84}$ Así, cuando la novela pone el foco en las tonadilleras españolas y los corrales de comedias en Lima, no deja en el tintero la modificación de la tradición trasplantada, por ejemplo, en estas líneas: «también había boleras, mojigangas, fandangos, jotas, pavanas, gallardas, canarios, y el baile del país, conocido como zarabanda. Pero Micaela tenía su preferida y cada vez que podía, movía el cuerpo a los tonos quechuas de la chacona para desde allí, cantarse a sí misma y a todo Lima». ${ }^{85}$ Así, el personaje incorpora la tonalidad quechua en un baile español a través de esta imagen que, como concluye, es la representativa de «todo Lima», es decir, de su idiosincrasia mestiza.

Sobre el mestizaje y el sentimiento americanista, es importante también la referencia a los cuadros que contienen el sistema o sociedad de castas colonial, que de hecho el virrey Amat envió al rey Carlos III, ${ }^{86}$ dato que aparece en la novela: «Un año más tarde, el virrey Amat enviaría al rey Carlos III sus cuadros del mestizaje, donde estaban representadas todas las posibilidades de la mezcla de razas en el Perú, con los nombres de cada una» ${ }^{87} \mathrm{~A}$ partir de este hecho de base histórica, el novelista insiste una vez más en configurar a un virrey que encumbra la ciudad desde el punto de vista de la defensa del mestizaje y, por tanto, desde la visión positiva de este entrecruzamiento social, racial, cultural que, sin duda, quiere resaltar con esta mirada hacia el pasado que, al tiempo, es una visión ideológica del presente: «esta es la mejor ciudad del mundo para vivir [...] Porque aquí

83 Ibidem, 111.

84 Sobre el concepto de transculturación, véase Ortiz, 2002 [1940] y Cornejo Polar, 1994, entre otras numerosas referencias bibliográficas que exploran y analizan el concepto acuñado por Ortiz.

85 Cueto, 2019, 65.

86 Se trata de una serie de cuadros de mestizaje, que fue un encargo realizado por el virrey Amat para dar a conocer en Europa las mezclas raciales existentes en el Virreinato de Perú. Véase Moreno Navarro, 1973, 111-113 y 240; Estenssoro et al., 1999.

87 Cueto, 2019, 186. 
hay gente de todos lados, todas las gentes en un mismo sitio. No hay nada mejor [...] No hay mejor lugar para soñar, con tanta gente tan distinta». ${ }^{88}$

Por otro lado, y en el mismo orden de cosas, la incorporación de otros acontecimientos históricos fundamentales del siglo XVIII coadyuva en la novela a la construcción del virrey en su dimensión moderna e ilustrada. Así ocurre también con la expulsión de los jesuitas, sobre la que Amat expresa de inmediato el desacuerdo y el disgusto, así como también la imposibilidad de oposición al poder monárquico:

El veinte de agosto de 1767 llegó en sobre fuertemente lacrado la orden de expulsión de los jesuitas [...] por Dios. ¿Tenía que expulsar a los jesuitas porque lo ordenaba el rey? [...] Él había sido alumno de los jesuitas. Expulsarlos era una traición, también un error ${ }^{89}$

Tras la expresión de oposición, Cueto explica, a través del virrey, la idiosincrasia de la orden jesuítica y la conocida influencia decisiva que esta tuvo en la América colonial, en todas las esferas de la realidad, tanto en lo referente a la posesión de tierras y el desastre venidero a consecuencia de la expulsión, como en lo que respecta a la relación con la población indígena, el proceso evangelizador transcultural y el proyecto educativo:

Los jesuitas habían hecho contactos con la población nativa. Son un nexo con la gente de aquí, han estado en sus tierras, los conocen, los indígenas creen en Dios gracias a ellos. Expulsarlos del virreinato es una injusticia, se dijo. Y qué error, Diablos. No lo quería hacer. Al quedar ellos fuera, al perderse ese vínculo precioso que los jesuitas tenían con los nativos, solo podía haber mayor distanciamiento y mayor violencia. Era un error político por donde se viera. ${ }^{90}$

Directamente relacionado con la expulsión se encuentra también otro tema cardinal del siglo ilustrado en América, la persecución del libro por la Inquisición, que aparece con la referencia explícita a los Anales de la compañía, con la que de nuevo se insiste en el espíritu ilustrado del virrey catalán:

La Santa Inquisición está muy molesta porque tengo ese libro. Pero yo lo voy a leer hasta aprovechar todo lo que aparece allí. —-Los de la Inquisición son unos monigotes - le dijo ella. - Unos bribones, más bien, diría yo. Para darte una idea, ellos no quieren que nadie lea y a mí me gustan los libros. Ya le voy a hacer su biblioteca a

88 Ibidem, 207.

89 Ibidem, 121.

90 Idem. 
Feijoo de Sosa con todos los libros que me interesan y que los de la Inquisición odian. También quieren prohibir los Comentarios Reales del Inca Garcilaso, un libro que es una delicia, te lo digo. Algún día van a reconocer su grandeza. ${ }^{91}$

Con esta crítica decidida y abierta a la Inquisición, Cueto introduce como vemos la prohibición de los Comentarios reales del Inca Garcilaso de la Vega, que se produjo por real cédula de 21 de abril de 1782. El novelista configura al virrey como lector admirado de la obra, ante la cual realiza una encarecida alabanza, vislumbrándola en su futura fama. Esta prohibición aparece en otro momento reunida con la de la cátedra de quechua en la Universidad de San Marcos, ${ }^{92}$ así como con la brutal represión de la rebelión de Tupac Amaru II. La novela no deja pasar la oportunidad de realizar la denuncia a la tremenda crueldad del castigo sufrido por Tupac Amaru, que aparece como héroe contra los abusos de las minas, y no en pro de la Independencia, y a quien se configura como un hombre culto, lector de los Comentarios y del Ollantay, como obras paradigmáticas de la cultura inca, pero también de las Siete partidas de Alfonso el Sabio, creando así un perfil de amplia cultura que no desestima la occidental. ${ }^{93}$ En este momento, el novelista tampoco pierde la ocasión de enfocar a su mujer, Micaela Bastidas, como una «mujer extraordinaria» ${ }^{94}$; de hecho, una de las grandes heroínas de la historia del Perú.

Todos estos acontecimientos que, como es bien conocido, coincidieron a fines del siglo XVIII y fueron revulsivo fundamental en el camino hacia la Emancipación, se produjeron en el virreinato que vivía estos años con la mirada puesta en los grandes acontecimientos continentales que también se encuentran en la novela. Así, vemos la incipiente fragmentación territorial con la aparición de nuevos virreinatos: «Pronto va a crearse el virreinato del Río de la Plata. Ya perdimos Nueva Granada y ahora esto. El Virreinato del Río de la Plata va a hacer su capital en una ciudad que se llama algo así como Santa María del Buen Aire. Creo. Está junto a un río que es un mar». Y con ello la pérdida de hegemonía del Perú («El virreinato del Perú va perdiendo territorio»), frente a la cual, sin embargo, prevalece nuevamente el tópico, el de la ciudad mítica, hortus clausum idílico: pero «Lima seguirá siendo la capital de la gracia y del espíritu». ${ }^{95}$

91 Ibidem, 165.

92 Ibidem, 318.

93 Ibidem, 337-338.

94 Idem.

95 Ibidem, 274. 
Los acontecimientos del norte continental serán también fundamentales hacia el final de la novela, con los anuncios sobre la inminente Independencia de América del Norte ( Pronto se va a crear un nuevo país, ya lo verás. Los ingleses tendrán que irse» $)^{96}$ que muy pronto se precipitaría, determinando el porvenir del continente entero: «El cuatro de julio de ese año había surgido un nuevo país, los Estados Unidos de América. Era el inicio de la liberación de todo el continente». ${ }^{97} \mathrm{~A}$ ello se une la referencia ineludible a la revolución francesa y a la invasión napoleónica, con la que aquel afrancesamiento del virrey Amat quedaría clausurado obviamente por los nuevos mandatarios; así, por ejemplo, surge en la obra la prohibición por parte del virrey Gil de Taboada de novelas, libros, franceses: «Que nada francés venga a Lima».98

Las páginas finales de la novela, coincidiendo con los últimos tiempos de vida de la Perricholi, están dedicadas a la irrupción de los cambios: «Por entonces todo Lima había entrado en un estado de alboroto [...] todas las revueltas que han empezado en Arequipa, Cusco, Junín». ${ }^{99}$ En la novela, Micaela asume este proceso como necesario: «-Revueltas en todos lados. En Buenos Aires, Santiago, México. En todas partes, gritos de independencia. —Creo que es mejor — dijo Micaela—. Es lo mejor. Esto de la Colonia se tiene que acabar» ${ }^{100}$ Un fin que comienza su deriva última con la noticia cardinal: «En 1808 llegó la noticia. Napoleón había invadido España y había ocupado Madrid. Había designado a un rey nuevo, su hermano José». ${ }^{101}$

Llegados al desenlace, Alonso Cueto concluye la novela con la desaparición de toda esa época que ha condensado magistralmente en sus páginas; un final que construye recogiendo la misma clave que, como se ha visto, es eje fundamental para la edificación de la Lima colonial como teatro y escenario, esto es, el contraste, la oposición de mundos en un solo mundo conviviendo sin la armonía que estuvo en el objetivo, finalmente frustrado, del virrey Amat:

El nuevo mundo había llegado. Todo parecía desmoronarse [...] Eran demasiados siglos de virreyes y de chalecos con borlas y de pelucas y de carrozas toradas por cuatro o seis mulas, y de frases azucaradas y de dedos en el aire, y de polvos y talcos y

96 Ibidem, 275.

97 Ibidem, 299.

98 Ibidem, 366.

99 Ibidem, 365.

100 Ibidem, 380 .

101 Ibidem, 423. 
cremas, y de órdenes que llegaban desde muy lejos y que tardaban meses en saberse, y de miserables abusos en las minas contra los indios y de leyes ajenas en un lenguaje incomprensible [...] El mundo avanzaba, había cada vez más gente en la calle y los condes y las condesas salían cada vez menos a la plaza.

Esas caras blancas y empolvadas aparecían todavía junto a la catedral pero una nube de incertidumbre las cubría. Veían con un escalofrío, cada vez más cerca, los rostros de los otros, los mendigos, los vendedores y hasta los religiosos que caminaban cerca de ellos. En las casonas se comentaban algunos de los levantamientos. En Cusco, en El Mantaro, en Trujillo, en Arequipa. ${ }^{102}$

En este fragmento, la denuncia al desequilibrio y el abuso que tal orden impuso, la semilla del cambio urbano que eclosionaría en pleno siglo XX con el desplazamiento social de la antigua aristocracia y que estaría en el objetivo de tantos escritores hasta bien entrado dicho siglo, y la imagen ya omnipresente de «los rostros de los otros» que transformarían el rostro de la ciudad ${ }^{103}$, son las claves de este desenlace que sintetiza sabiamente este momento crucial en la historia del Perú. Estas claves se complementan con un último párrafo en el que Cueto ha querido enfocar el analizado concepto del teatro urbano en ese momento en el que el futuro se imponía de forma perentoria y, con él, el teatro mestizo como vislumbre desde el tiempo narrado, el siglo XVIII, y como certeza desde el tiempo del narrador, el XXI. Así, la novela termina con una visión de apertura hacia un mundo venidero que estaría en el foco de los autores a partir del siglo XIX:

Miraba la gente pasar. Todos en busca de un futuro desconocido, los vendedores, los comerciantes, los nuevos soldados. Los peruanos, los argentinos, los chilenos, los colombianos, los venezolanos, los españoles, los franceses, los ingleses, los italianos. Los blancos, los indios, los negros, los chinos. Los quechuas, los mochicas, los nazcas, los tallanes, los aymaras, y esos amazónicos de los que había oído, los aguarunas, los machiguengas, los huambisa, los asháninlas. Todos. Qué sería de esa ciudad, de ese país, de él mismo. ${ }^{104}$

\section{Conclusiones}

A través del análisis de los ejes fijados como objetivo del presente estudio de La Perricholi. Reina de Lima, esto es, literatura y ciudad, e historia y literatura, se ha podido comprobar cómo esta novela de Alonso Cueto publicada en 2019 recoge las grandes líneas por las que ha discurrido la

102 Ibidem, 417.

103 Véase Matos Mar, 1998.

104 Cueto, 2019, 440. 
literatura que en el Perú se ha dedicado a la construcción de la ciudad. Desde las herramientas que aporta la novela histórica, el narrador ha creado una obra que dialoga no solo con la historia sino con toda la tradición literaria, produciendo una intertextualidad que, sin ser explícita, densifica y sintetiza toda una serie de claves reconocibles a lo largo de la tradición literaria peruana. Así, la idea de continuidad señalada por varios críticos e historiadores de la literatura peruana - Cornejo Polar planteó una «secuencia viva ininterrumpida, capaz de prolongarse hacia el futuro» ${ }^{105}$ para identificarla - se hace patente, como hemos visto a lo largo de estas páginas, en la recreación de personajes y claves históricas que caracterizan la tradición literaria peruana. Fundamentalmente, la mitificación y la crítica en lo que respecta a la historia de Lima en la literatura se condensan en la novela. Hay que remarcar, asimismo, como una de las conclusiones principales, que la utilización de la historia no se queda en lo meramente contextual y de época, sino que adquiere una especial relevancia para la configuración novelesca de los personajes históricos, en tanto que, como hemos comprobado, se la instrumentaliza para delinearlos literariamente en toda su complejidad.

Así, la historia novelada de la Perricholi, que engarza con todo el corpus textual, musical y cinematográfico por ella protagonizado, siendo fundamental para la historia literaria de este personaje y del virrey Amat - cuya fama se debe a su romance con Micaela Villegas-, es una parte de la novela. Tal y como he planteado al comienzo de estas páginas, el protagonismo es compartido por Micaela Villegas y por la ciudad, cuya fusión estuvo determinada precisamente por la literatura generada en torno al mítico personaje. Así, sobre la gran novela dedicada a la Perricholi, se erige la novela cardinal de la Lima colonial generada por la literatura peruana contemporánea. Sus contornos físicos, espirituales, culturales, míticos y reales, son perfilados por Alonso Cueto en términos abarcadores no solo de su historia, sino de la literatura que esa historia generó. En este sentido, la novela es la obra que, desde el siglo XXI, recoge las esencias de la historia y de la literatura que a lo largo de los siglos edificó el devenir de una ciudad cuya neblina no ha impedido al escritor encontrar la luz con la que iluminar todas sus facciones, con el objetivo puesto en el pasado, pero con la mirada también instalada, de reojo, en el presente de Lima, y del Perú.

Recibido, 9 de diciembre de 2019

Aceptado, 17 de marzo de 2020

105 Cornejo Polar, 1989, 61. 


\section{Referencias bibliográficas}

Camacho, José Manuel, «Alonso Cueto y la novela de las víctimas», Caravelle, 86, Toulouse, 2006, 247-264.

Cañas, Dionisio, El poeta y la ciudad. Nueva York y los escritores hispanos, Madrid, Cátedra, 1994.

Castro Arenas, Mario, De Palma a Vallejo, Lima, Populibros Peruanos, 1964.

Cornejo Polar, Antonio, La formación de la tradición literaria en el Perú, Lima, Centro de Estudios y Publicaciones, 1989.

Cornejo Polar, Antonio, «Mestizaje, transculturación, heterogeneidad», Revista de Crítica Literaria Latinoamericana, 40, Lima/Berkeley, 1994, 368-371.

Cornejo Polar, Antonio, «Una heterogeneidad no dialéctica: sujeto y discurso migrantes en el Perú moderno», Revista Iberoamericana, 62, 176-177, Pittsburg, 1996, 837-844.

Cornejo Polar, Antonio, «Mestizaje e hibridez: Los riesgos de las metáforas. Apuntes», Revista de Crítica Literaria Latinoamericana, 48, Lima/Berkeley, 1998, 7-11.

Cueto, Alonso, La Perricholi. Reina de Lima, Lima, Random House, 2019.

Elmore, Peter, Los muros invisibles. Lima y la modernidad en la novela del siglo XX, Lima, Mosca Azul Editores, 1993.

Estenssoro, Juan Carlos; Romero de Tejada y Picatoste, Pilar; Wuffarden, Luis Eduardo y Majluf, Natalia, Los cuadros de mestizaje del virrey Amat; La representación etnográfica en el Perú colonial, Lima, Ministerio de Educación y Cultura/Museo de Arte de Lima, 1999.

García Calderón, Ventura, Vale un Perú, París, Desclée, 1939.

García Gual, Carlos, Apología de la novela histórica y otros ensayos, Barcelona, Península, 2002.

Hopkins R., Eduardo, «El teatro de Julio Ramón Ribeyro», Revista de Crítica Literaria Latinoamericana, 20, Lima/Berkeley, 1984, 129-153.

Lukács, George, La novela histórica, Madrid, Ediciones Era, 1966.

Matos Mar, José, Desborde popular y crisis del Estado, Lima, José Matos Mar Editor, 1988.

Miró Quesada, Aurelio, Lima, Ciudad de los Reyes, Buenos Aires, Emecé Editores, 1946.

Miró Quesada, Aurelio, Lima, tierra y mar, Lima, Juan Mejía Baca, 1958.

Moreno Navarro, Isidoro, Los cuadros de mestizaje americano. Estudio antropológico del mestizaje, Madrid, Porrúa Editorial, 1973.

Ortega, Julio, Cultura y modernización en la Lima del 900, Lima, Centro de Estudios para el Desarrollo y la Participación, 1986.

Ortiz, Fernando, Contrapunteo cubano del tabaco y del azúcar, Madrid, Cátedra, 2002 [1. ${ }^{\mathrm{a}}$ ed. 1940]. 
Palma, Ricardo, Tradiciones peruanas, Barcelona, Montaner y Simón, tomo II, 1894.

Paradas, Rocío, Grandes miradas, La hora azul y La pasajera de Alonso Cueto: el crepúsculo del desastre, Sevilla, Diputación de Sevilla, 2018.

Porras Barrenechea, Raúl, Pequeña antología de Lima. El río, el puente y la alameda, Lima, Instituto Raúl Porras Barrenechea, 1965.

Porras Barrenechea, Raúl, Mito, tradición e historia del Perú, Lima, Peisa, 1974.

Ribeyro, Julio Ramón, Antología Personal, México, Fondo de Cultura Económica, 1994.

Ricoeur, Paul, Tiempo y narración III. El tiempo narrado, Madrid, Siglo XXI, 2009.

Rovira, José Carlos, «Heterogeneidad y discursos conflictivos», Revista de Crítica Literaria Latinoamericana, 25:50, Lima/Hanover, 1999, 107-111.

Sánchez, Luis Alberto, Don Ricardo Palma y Lima, Lima, Imprenta Torres Aguirre, 1927.

Sánchez, Luis Alberto, La Perricholi, Buenos Aires/Santiago de Chile, Editorial Francisco de Aguirre, 1971.

Sánchez, Luis Alberto, «Panorama cultural del Perú» [1951], en Sánchez, Luis Alberto, La vida del siglo, edición de Hugo García Salvattecci, Venezuela, Biblioteca Ayacucho, 1988, 33-50.

Terralla y Landa, Esteban de, Lima por dentro y fuera, Lima, Tadeo López, 1838.

Ugarte Elespuru, Juan Manuel, Lima y lo limeño, Lima, Editorial Universitaria, 1967.

Valero Juan, Eva, Lima en la tradición literaria del Perú. De la leyenda urbana a la disolución del mito, Lleida, Universitat de Lleida, 2003.

Valero Juan, Eva, «De la Colonia a la República en el teatro de Julio Ramón Ribeyro: Santiago el pajarero y Atusparia», en Aracil, Beatriz; Ferris, José Luis y Ruiz Bañuls, Mónica (eds.), América Latina y Europa. Espacios compartidos en el teatro contemporáneo, Madrid, Visor, 2015, 159-171.

Vidal, Luis Fernando; Escajadillo, Tomás G. y Sánchez León, Abelardo, Presencia de Lima en la literatura, Lima, Centro de Estudios y Promoción del Desarrollo, 1986. 